Published in Proceedings of the Geologists' Association, 2015, Volume 126,

266-281.

Note that this version of the text does not include the Journal's editorial and proof

corrections

\title{
Geological exploration of South Atlantic islands and its contributions to the continental drift debate of the early $20^{\text {th }}$ century
}

\author{
Philip Stone \\ British Geological Survey, Murchison House, West Mains Road, Edinburgh EH9 3LA, Scotland, UK. \\ E-mail: psto@bgs.ac.uk
}

Key Words: South Atlantic Ocean, Scotia Arc, Falkland Islands, South Georgia, Gondwana, continental drift.

\begin{abstract}
The geological character of the South Atlantic islands was only slowly established during the first half of the $20^{\text {th }}$ century. That same period was marked by a generally dismissive view of continental drift but, as the continental nature of the islands became apparent, their 'oceanic' setting was utilised by both sides of the 'drift' debate to support their respective positions. So islands such as the Falklands archipelago and South Georgia were cited either as fragments detached from larger continental bodies during drift, or as the last surviving vestiges of a huge continental landmass that had subsided beneath the water of the South Atlantic. The appreciation of the Scotia Arc as a dynamic geological construct arising from lateral tectonics, and the Falkland Islands as representative of an itinerant continental fragment, were features of some early accounts of the region, but such ideas were generally discounted by the geological establishment of the day. This paper reviews the early, pioneering contributions to the geological understanding of the Falkland Islands, South Georgia and the Scotia Arc region, assessing their contemporary reception and tracing their influence on the developing continental drift controversy. Though commonly dismissed or ignored at the time, many of the 'pro-drift' ideas expressed were subsequently rediscovered by proponents of plate tectonics as that revolution swept through geology in the late 1960s.
\end{abstract}

\section{Introduction}

The continental drift debate of the early $20^{\text {th }}$ century was largely provoked by the publications of Alfred Wegener (1912, 1915, 1922), albeit he was not the only advocate for the concept at that time. The largely negative response, particularly from the geological establishment in the United States of America, has been extensively researched and documented (Newman 1995; Oreskes 1999); the more ambivalent, but still mostly dismissive view from Europe has been summarized by Wood (1985). Its 
generally hostile reception in the Northern Hemisphere ensured the theory's quiescence until the plate tectonic revolution of the late 1960s.

In the Southern Hemisphere things were rather different. The evidence for a preAtlantic contiguity between Africa and South America was particularly compelling. The broad geological associations had been cited by Wegener and some detailed correlations had been noted by the Argentine geologist Juan Keidel (1916), but these were systematically assessed and analysed by the South African geologist Alexander Du Toit (1927), who was to prove the most influential of the early champions of continental drift. Du Toit (1937) attempted to assimilate the islands of the South Atlantic, the Falklands and components of the Scotia Arc such as South Georgia (Figure 1), into his pre-drift reconstruction of the South Atlantic region, but at the time their geology was poorly known. This made it possible for their alternative incorporation into fundamentally different, anti-drift interpretations. As geological knowledge of the islands grew, pro-drift interpretations were favoured, and much of the relevant work was carried out by British-based geologists. They formed a small, pro-drift coterie but had only limited influence on mainstream British opinion and the detail of their work was largely neglected, overwhelmed by the negative position on drift held by influential figures in the British scientific establishment. With the advent of plate tectonics, some of the original interpretations from the South Atlantic were then 'rediscovered' by proponents of the new model. This paper seeks to examine the development of continental drift interpretations for the islands of the South Atlantic, focusing particularly on the Falkland Islands and South Georgia, and to trace the assimilation of those interpretations by the plate tectonics paradigm.

The Falkland Islands are centred some $600 \mathrm{~km}$ east of the South American mainland in the south-west part of the South Atlantic Ocean at the western end of the Falkland Plateau (Figure 1), a rectilinear, relatively shallow water ( $<2500 \mathrm{~m}$ approximately) bathymetric feature that extends eastwards from the South American continental shelf. The archipelago is a British Overseas Territory but is also claimed by Argentina as Las Islas Malvinas. To the south of the Falkland Plateau, the Scotia Arc is formed by the islands and submarine banks that link Tierra del Fuego, in southernmost South America, with Graham Land, in the north of the Antarctic Peninsula, and which together enclose the Scotia Sea in a huge, eastward-closing physiographic loop. The name celebrates the Scotia, the ship that carried the Scottish National Antarctic Expedition, 1902-1904, and from which bathymetric survey work first confirmed the existence of the arcuate submarine ridge (Bruce 1905). Many early workers referred to the Scotia Arc as the Southern Antilles or South Antilles Arc, after the perceived similarity to the island chain enclosing the Caribbean Sea, but 'Scotia Arc' has been in general use following Herdman (1932), although the term remains an unofficial geographical name sensu stricto (Hattersley-Smith 1980). In this account, 'Scotia Arc' will be used as a collective reference for the formally-named North and South Scotia ridges, their component islands, and the South Sandwich Islands volcanic chain that links their eastern extremities (Figure 1). The island of South Georgia, another British Overseas Territory claimed by Argentina, as Isla de San Pedro, is the largest topographical feature of the North Scotia Ridge.

As precursors to this paper's assessment of the historical contributions, brief reviews of the modern geological interpretations of the Falkland Islands and South Georgia are appropriate. For the Falkland Islands (Figure 2), comprehensive accounts, 
bibliographies and modern geological maps are provided by Aldiss and Edwards (1998, 1999) and by Stone et al. (2005). South Georgia's geology (Figure 3) has been summarized and illustrated by Macdonald et al. (1987) and Curtis and Riley (2011). For a comprehensive modern assessment of the Scotia Arc, as its origin and evolution are now most commonly interpreted, see Dalziel et al. (2013).

The oldest Falkland Islands rocks are the $c a 1000$ million years old, granite and gneiss of the Proterozoic Cape Meredith Complex, which has a restricted coastal outcrop on the southernmost point of West Falkland. This 'basement' complex is unconformably overlain by the West Falkland Group, a thick succession of fluvial to neritic and shallow marine, clastic strata ranging in age from Silurian to Devonian: a fossiliferous unit in the middle of the group (Fox Bay Formation) is early Devonian in age. The West Falkland Group underlies most of West Falkland and the northern part of East Falkland. In the southern part of East Falkland a younger succession of strata, the Lafonia Group, has near its base (the northern margin of its outcrop on Figure 2) an Early Permian glacigenic unit (Fitzroy Tillite Formation) and passes upwards into a thick succession of Permian, deltaic and pro-delta basinal (probably lacustrine) strata. The metamorphic and sedimentary rocks are cut by swarms of Early Jurassic and Early Cretaceous dolerite dykes (Richards et al. 2013 and references therein).

Much of South Georgia is underlain by a thick succession of Lower Cretaceous volcaniclastic sandstone and mudstone (Cumberland Bay Formation) originally deposited by deep-marine turbidity currents. The strata were then asymmetrically folded and thrust towards the north-east to structurally overlie a more intensely deformed and cleaved succession of quartzo-feldspathic turbidites (Sandebugten Formation), which may nevertheless be of a similar Cretaceous age. A major shear zone separates the Cumberland Bay and Sandebugten formations and broadly similar (but still more deformed) sedimentary rocks (Cooper Bay Formation) from a very different lithological assemblage that forms the south-east end of the island: gneiss intruded by probably Triassic granite (Drygalski Fjord Complex) and minor associated metasedimentary formations, Upper Jurassic lavas and volcaniclastic rocks (Larsen Harbour Complex) and Lower Cretaceous tuff (Annenkov Island Formation). In total, the geology of South Georgia illustrates an active continental margin split by the opening of an island arc and back-arc basin system, with the subsequent closure of the basin and deformation of its sedimentary fill (key references listed by Macdonald et al. 1987 and Curtis and Riley 2011).

\section{Geological pioneers in the Falkland Islands}

The first recorded geological observations in the Falkland Islands were made by Charles Darwin during two visits to the archipelago by HMS Beagle, in 1833 and 1834. Darwin described a folded and cleaved succession of quartzite, sandstone and mudstone, from which he recovered Devonian fossils, mostly brachiopods (Darwin 1846; Morris and Sharpe 1846). In a footnote to his 1846 paper, Darwin recorded the dolerite dyke swarm that had been discovered and reported to him by Bartholomew Sulivan in 1845 (Stone and Rushton 2013). Little more was added until two Swedish expeditions visited the Falkland Islands: the Swedish South Polar Expedition (19011903) and the Swedish Magellanic Expedition (1907-1909). Reporting after these 
expeditions, Andersson (1907a) and Halle (1911) recorded the presence on West Falkland of the 'basement' granite-gneiss complex, expanded the range of the Devonian fauna to include trilobites, gastropods and bivalves, clarified the Palaeozoic stratigraphy and extended it into the Permian with the discovery of a fossil Glossopteris flora, and described a glacigenic tillite unit (now the Fitzroy Tillite Formation) that Halle correctly correlated with the Upper Carboniferous to Lower Permian Dywka tillites of South Africa (a correlation seized upon by Wegener (1922, 1929) in the $3^{\text {rd }}$ and $4^{\text {th }}$ editions of his book Die Ehtstehung der Kontinente und Ozeane). The association of Falklands and South African geology had been noted earlier on palaeontological grounds, and with evident surprise, by Sharpe and Salter (1856) and was reiterated by Clarke (1913) in his seminal work on the Devonian 'Malvinokaffric' fauna of South America and the Falkland Islands.

Although Halle (1911) had included an outline geological map of the Falkland in his report, the first attempt at comprehensive geological mapping was by Baker (1924), 'Government Geologist' from 1920 to 1922 and principally concerned with mineral prospecting. In that respect he was unsuccessful, but his work laid the foundations for the modern interpretation of Falklands geology, and he notably utilised Wegener's recently formulated ideas of continental drift to explain the geological similarities with South Africa. Baker's geological map was at a relatively small scale (an accurate topographical base map for the Falklands was not produced until the late 1950s) and was only available as a fold-out figure within his relatively obscure 1924 report. Nevertheless, for fifty years it remained the definitive representation of Falkland Islands geology until the publication by the British Antarctic Survey of a photogeological interpretation by Greenway (1972), who utilised much of Baker's (1924) lithostratigraphy. In the interim, and with no additional fieldwork, Baker's map and cross-section had been reproduced in a Spanish-language review by Borrello (1963) published in Argentina. Borrello emphasised perceived geological correlations with South America from which 'Las Malvinas' were figured as a continental promontory.

\section{Geological pioneers in South Georgia}

The first record of geological specimens being collected at South Georgia dates from 1871 when R.W. Chappell, an American whaling captain, gathered a number of beach pebbles that he later presented to Yale University. These pebbles eventually found their way to Scotland, to Glasgow University, where they were described (as metasedimentary rocks) along with other specimens from the island by Tyrrell (1916). Had the nature of Chappell's specimens been known earlier, the description of South Georgia's rocks by Klutschak (1881) might have been rather different. Klutschak, an Austrian adventurer, accompanied a sealing expedition to South Georgia in 1877. He was no geologist, writing (1881: 1967 English translation p. 88): “The island's formation is that of a mountain range some 4,000 to 5,000 ft in height, a range of once mighty but now extinct volcanoes which only reveal their former activity in their sharp, cone-shaped peaks and great beds of lava.” A truer picture emerged during the German International Polar Year Expedition (1882-1883) when rock specimens were collected and subsequently described by Thürach (1890) as phyllites, argillaceous slate, tuff and 'greenstone'. The expedition's activities were restricted to the Royal Bay are where the phyllite, tuff and slate can all be matched with lithologies exposed within the Sandebugten and Cumberland Bay formations (Stone 1980); the 
'greenstone' could refer to altered dolerite found in rare intrusive sheets. The geological discoveries of this and other early expeditions that passed through South Georgia have been briefly summarised by Adie (1957a).

The German expedition found no fossils so had no evidence for the age of the South Georgia rocks. The first clue to that was obtained twenty years later, when members of the Swedish South Polar Expedition (1901-1903) visited the island during the 1902 austral winter. Andersson (1907b) discovered in Moraine Fjord (Figure 3) a fossil bivalve that was indicative of a late Palaeozoic or early Mesozoic age. He was clearly well-aware of the importance of the discovery, recounting (Nordenskjöld and Andersson 1905, p 362) that recovery of the specimen took four men two days, and involved rock drills and blasting powder. The fossil was found in strata that would now be assigned to the Cumberland Bay Formation.

Contemporary with the Swedish expedition was the Scottish National Antarctic Expedition (1902-1904). The Scots did not visit South Georgia, but it was bathymetric survey work carried out from the expedition ship, Scotia, which first identified the arcuate submarine ridge - the Scotia Arc - of which South Georgia is the largest emergent feature (Bruce 1905). The expedition spent much time in the South Orkney Islands and geological work there came to have a significant influence on interpretations of South Georgia. In rocks that were superficially similar to those of South Georgia, the discovery of a graptolite was reported by Pirie (1905), which supposedly established an Early Palaeozoic age. There will be more on Pirie's putative graptolite latter in this narrative.

Back on South Georgia, a considerable advance in geological knowledge was contributed late in 1911 by the German South Polar Expedition (1911-1913). Heim (1912) described the bulk of the island as comprising dark shales and greenish tuffs, with a poorly preserved ammonite found at Prince Olav Harbour seeming to confirm a Mesozoic age for the rocks. As with Andersson's bivalve, the ammonite was found in strata that would now be assigned to the Cumberland Bay Formation. The other major discovery reported by Heim was the presence of a substantial body of igneous rocks at the south-east end of the island, now divided between the intrusive and metamorphic rocks of the Drygalski Fjord Complex and the volcanogenic Larsen Harbour Complex.

Shortly after the departure of the German expedition, the first attempt at a comprehensive geological assessment of South Georgia began. This was a strictly commercial affair initiated by the Christian Salvesen Whaling Company soon after that enterprise had established an onshore whaling station in Stromness Bay in 1909, naming it Leith Harbour after the company's home port in Scotland. David Ferguson, an experienced Scottish geologist and mine surveyor who had close connections with the Geology Department at the University of Glasgow, was employed to carry out the prospecting work. His investigations at South Georgia (and subsequently in the Falkland Islands and the South Shetland Islands) have been assessed in detail by Stone and Faithfull (2013).

Ferguson arrived at Leith Harbour on 7 January 1912, only a month after the departure of the German expedition. Though he would have known nothing of the detail of their work, he acquired some information on their findings from staff at the 
whaling stations. For example, he was shown a sketch of the poorly preserved ammonite from Prince Olav Harbour that was supportive of the Mesozoic age previously suggested by Andersson's bivalve. But Ferguson doubted the identification of the fossil and prematurely dismissed the possibility of a Mesozoic age since he had rapidly formed the opinion that the South Georgia rocks were very much older than that. Ferguson knew of Pirie's putative graptolite from the South Orkney Islands, and had discussed the geology of that archipelago with William Speirs Bruce (leader of the Scotia expedition) before departing for South Georgia (Stone and Faithfull 2013). Ferguson favoured a correlation between the superficially similar rocks from the two Scotia Arc components, so saw Pirie's fossil as indicative of an Early Palaeozoic age for at least part of the South Georgia succession. Pirie concurred. In Glasgow he saw Ferguson's specimen collection whilst preparing a contribution to the planned eighth volume in the series of Scotia scientific reports. This volume was never published but a galley proof of Pirie's intended contribution, a description of the geology of the South Orkney Islands (Pirie 1913), is held by the British Antarctic Survey. In it, Pirie wrote that Ferguson's South Georgia specimens “present remarkable similarity to the greywackes of the South Orkneys, and I think it extremely probable that they will prove to be, if not of identical age, at least older than Upper Palaeozoic.”

Overall, the South Georgia sedimentary succession was interpreted by Ferguson as a conformable series of three divisions, the middle of which was locally unconformable on much older sedimentary strata with a more complex structural history that formed two small inliers at Cumberland East Bay and Godthul (Figure 3). He was partially correct in that the intensely folded and cleaved succession now assigned to the Sandebugten Formation has been overthrust by the less pervasively deformed Cumberland Bay Formation in Cumberland East Bay (Dalziel et al. 1975) and at Godthul and around Royal Bay (Stone 1980), but there is no unconformity. Ferguson paid little heed to the effects of the widespread and large-scale folding when constructing his geological map. This led to some unlikely outcrop patterns and it is odd that his experienced mentors at Glasgow University, Professor J.W. Gregory and Dr G.W. Tyrrell, did not identify this fundamental problem prior to the publication of their three complementary papers in the Transactions of the Royal Society of Edinburgh (Ferguson 1915; Gregory 1915; Tyrrell 1915). Perhaps Tyrrell's focus was entirely on petrography, whilst in his comprehensive biography of Gregory, Leake (2011, p. 146) notes that the interpretations of South Georgia “reveal Gregory's poor knowledge of structural geology.”

It was not long before Ferguson's interpretation was challenged. Shackleton's ill-fated Endurance expedition had called at South Georgia on its voyage south in November 1914, and the expedition's geologist, J. M. Wordie (another of Gregory’s protégés), had done much geological work during a stay of about four weeks. Despite the subsequent vicissitudes of the Endurance expedition and being badly wounded during service with the Royal Field Artillery towards the end of the Great War, Wordie eventually published a summary of his geological observations. Therein (Wordie 1921, p. 19), he dismissed Ferguson's “unfortunate attempt at subdividing the sedimentary series” of South Georgia, supported its likely Mesozoic age, and stressed the importance of folding. By the time Wordie published, Shackleton had embarked on his final expedition (during which he died, at South Georgia, on 5 January 1921) aboard the Quest, with G. V. Douglas as geologist. In that expedition's report, Douglas (1930, p. 9) noted with respect to the geology of South Georgia: “J. M. 
Wordie's paper ... appeared after the Quest had sailed, and the present writer arrived independently at the conclusions to which Wordie had also come.” The rock specimens collected during the Quest expedition were described by Tyrrell (1930), in the last of his series of papers on South Georgia petrography. Macdonald et al. (1987) noted that these enabled Tyrrell, in his 1930 paper, to produce one of the best of the early stratigraphical schemes for South Georgia even though he never visited the island.

Wordie's conclusions had also been supported by Holtedahl (1929) who studied the geology of South Georgia during the Norwegian Antarctic Expedition (1927-1928). Holtedahl was able to examine much of the island and concluded that there was a single sedimentary succession of Mesozoic age. Expedition members found more fossils to support that age, notably a collection from Annenkov Island that included an ammonite and several types of bivalve. Holtedahl also provided more information about the igneous rocks in the SE of the island and recognised the highly sheared contact between igneous and sedimentary rocks that is now known as the Cooper Bay Shear Zone (Figure 3). Soon after Holtedahl's study, South Georgia was revisited during the 1928-1929 austral summer by L. Kohl-Larsen, who had first arrived in 1911 as a member of the German South Polar Expedition; on that occasion, appendicitis had forced him to leave the expedition and recuperate at the Grytviken whaling station. On his second visit, which was not primarily concerned with geology, Kohl-Larsen recovered more fossils from Annenkov Island. These, together with Holtedahl's collection, were formally described by Wilckens $(1932,1937)$ as being undoubtedly Early Cretaceous in age. Wilckens (1933) also attempted to integrate the geology of South Georgia into the broader pattern of the Scotia Arc, stressing that correlation with Tierra del Fuego was more likely than the links with the South Orkney Islands favoured by Pirie (1913) and Tyrrell (1915).

The resolution of South Georgia's geological structure was finally initiated in the 1950s by the work of A. F. Trendall during the first two of the three South Georgia Survey Expeditions (Trendall 1953, 1959; Carse 1959). Trendall thought it possible that the Cumberland Bay and Sandebugten formations represented facies (and/or provenance) variations within a single, thick succession of turbidite strata; the early Cretaceous age of the Cumberland Bay Formation was confirmed. He also provided much new information on the igneous rocks in the south east of the island (defining a 'South-eastern Igneous Complex') and attempted an explanation of the structural problems that invoked overfolding, refolding and thrusting. The development of these ideas by subsequent workers has been summarized by Macdonald et al. (1987) who stress (and list in their Table 1) the contributions of geologists from the British Antarctic Survey and the United States Antarctic Research Program; more recent contributions are noted by Curtis and Riley (2011).

\section{Early regional assessments of the Scotia Arc}

After his misidentification of South Georgia as a volcanic island, Klutschak (1881, English translation p. 88) continued, "[a]s regards its relation to other continents, South Georgia is part of a submarine range of high mountains connecting the uplands of South America with the Antarctic continent. The highest peaks of this range between Cape Horn and the Cape of Good Hope are represented by the Falkland 
Islands, South Georgia, the South Orkneys [and] the South Sandwich Islands. With the exception of the Falkland Islands ... they are all of the same volcanic nature."

The concept of a geological link between South America and the Antarctic Peninsula via the islands of the Scotia Arc was not a new idea. After sailing to the South Sandwich Islands from South Georgia at the beginning of 1820, the Russian explorer Thaddeus von Bellingshausen (1831) had proposed that these two features were "the summits of a mountain range" now submerged between them and continuing westward as a submarine ridge to the South American mainland via the Falkland Islands (1945 English translation, p. 110). At about the same time, Sir John Barrow (1831, p. 62), noted that the South Shetland Islands "seem to be a continuation of the cordillera of the Andes, and Archipelago of Tierra del Fuego; being for the most part precisely of the same formation with the latter \& their strata even inclining in the same way”. Barrow was not writing from first hand experience but, as Second Secretary to the British Admiralty (1804-1845), was well-placed to receive geographical intelligence.

The geological assumptions inherent in Barrow's account were naïve, inevitably so given the circumstances. A more informed assessment followed the Belgian Antarctic Expedition of 1897-1899, when Arçtowski (1895) concluded that the mountains of Graham Land were indeed the geological continuation of the Andes. A little later, in a discussion of the objectives of the proposed British National Antarctic Expedition, Gregory (1901) illustrated a continuation of the Andes into the Antarctic Peninsula via an eastward-closing loop (Figure 4), admittedly one that closed far to the west of South Georgia. The proposal that the Andes continued southwards to Graham Land via an eastward, horseshoe-shaped bend was then discussed in some detail by Suess (1909, 488-497). One possibility that he considered was that a submerged geological link followed the arcuate submarine ridge discovered during the 1902-1904 Scotia expedition (Bruce 1905) - the Scotia Arc (Figure 1) - but Suess, whilst supporting the broad idea, felt it more likely that the Andes to Graham Land connection linked Burdwood Bank with Elephant Island and the South Shetlands. This left the more easterly, poorly known islands such as South Georgia as geological enigmas. Suess had also noted the anomalous geology of the Falkland Islands, describing the archipelago as an "alien and divergent fragment". This assessment arose from the known similarity of Falkland Islands geology to that of South Africa, and its contrast to that of the adjacent part of South America; Suess cited the Falkland Islands work of Darwin (1846), Andersson (1907a) and Halle (1911). Halle's work arose from the 1907-1908 Swedish Magellanic Expedition, the results of which were clearly known to Suess prior to their formal publication. Despite these insights, Suess (who coined the name 'Gondwana-Land' in reference to the distribution of a so-called Gondwana flora, dominated by Glossopteris and named from a type-locality in India) regarded the continents and oceans as essentially permanent features with evidence for lateral tectonic movement explained in terms of a contracting Earth.

\section{The beginnings of the continental drift debate}

Like many important scientific concepts, continental drift had a long history of maverick (and in some cases bizarre) manifestations (reviewed by Wood 1985), but it only attracted the attention of the geological mainstream once promoted by Alfred Wegener from 1912 onwards (Wegener 1912, 1915, 1922, 1929). From the outset, the 
trans-Atlantic geological correlations between Africa and South America were recognized as crucial to the debate. Keidel (1916) had noted the geological similarities between the Ventania sierras of Argentina and the Cape Province of South Africa but, apart from Wegener himself, the most prominent champion of its interpretation in terms of continental drift was the South African geologist Alexander Du Toit. He, being familiar with their faunal connections, also appreciated the importance of the Falkland Islands and addressed the mis-match between their geology and their present-day geographical position. In his reconstructions of Gondwana, Du Toit $(1927,1937)$ was the first to move the islands into what seemed to be a more geologically appropriate position. His solution was to take them north to form a linear link between Keidel's comparable geological settings of Ventania and the Cape Province (Figure 5). In the fourth edition of his book Wegener (1929) commented approvingly, though stated a preference (unsupported by argument) for the Falklands to lie to the south of Africa rather than to the west. Regarding the Scotia Arc, Wegener insisted in both the $3^{\text {rd }}(1922)$ and $4^{\text {th }}$ (1929) editions of his book that its development was best explained by 'drift theory'. Both editions illustrated the bathymetry of the Scotia Arc region from which Wegener noted (e.g. 1929, p. 94) that "[i]n the depth chart one can clearly see how the echeloned chains were torn off seriatim from the drifting blocks and then left behind"

None of this impressed the implacable opponents of continental drift. Between 1926 and 1928 the USA's geological establishment had mounted a concerted, coordinated and successful assault on the theory (Newman 1995; Oreskes 1999) which, inevitably, had a negative effect on European opinion. In the prevailing view, the necessary intercontinental connections required by palaeobiogeography were provided by land bridges that had now foundered. An extensive review of these putative structures was given by Schuchert (1932) who reproduced as a starting point (1932, figure 1) Melchior Neumayr's palaeogeographical map from 1887. The vast 'Brazil-Ethiopian Continent' which Neumayr showed occupying the Jurassic South Atlantic as far south as the Falkland Islands had been extended by Gregory $(1922,1929)$ to include South Georgia and its Mesozoic fossils (Figures 6a and 6b), but it was reduced in Schuchert's (1932) Permian palaeogeography to a much more restricted 'bridge' linking Brazil and West Africa. Schuchert proposed another land bridge running from Tierra del Fuego to Graham Land via South Georgia and the South Orkney Islands, but cutting obliquely across the Scotia Sea to avoid the actively volcanic South Sandwich Islands for which there was no evidence of a continental basement.

In his preview of the British National Antarctic Expedition, Gregory (1901) had assumed that there was no geological similarity between South Georgia and Tierra del Fuego. This notion was subsequently challenged by both Wegener (1929) and Holtedahl (1929), but these two men had very different regional perspectives. Wegener (1929, p. 94) cited the geological relationships as "a model for demonstrating drift theory". In contrast, Holtedahl favoured predominantly vertical tectonic movements and was not convinced of the reality of continental drift, deciding (1929, p. 110) that "I can see nothing in the geological character of the whole area here discussed [the Scotia Arc] that speaks decidedly against the old theory of a connection through an old folding range. On the contrary, there are a number of important features in favour of it" - italics as in the original. So, whilst there might have been agreement that some sort of 'Scotia Arc' existed, there was no agreement as to its origins. 
The majority view undoubtedly favoured Holtedahl, and was influentially articulated by Gregory (1929) in his Presidential Address to the Geological Society of London. Therein, the Falkland Islands, South Georgia, and the other islands of the Scotia Arc were regarded as vestiges of a foundered continent that had once occupied the South Atlantic region. But there was also an informed alternative view. Arthur Holmes had established an absolute time-scale based on the decay rates of radioactive elements in igneous rocks and realised that the thermal effects of radioactive decay had implications for the continental drift debate. In a remarkably far-sighted paper published in the Transactions of the Geological Society of Glasgow, Holmes (1929) described a mechanism for continental drift based on deep thermal convection currents and amongst the detailed examples cited, referred to the Scotia Arc as arising from the westward drift of South America and Antarctica (1929, p. 595): “The island arc here is probably a lag effect due to a strung-out belt of sial having been dragged against part of the Pacific floor left between the two continental blocks as they advanced." This interpretation, similar in most respects to Wegener's earlier proposal, was clearly illustrated in Holmes' figure 7, partly reproduced here as Figure 6c. There has been much speculation that Holmes' choice of an 'obscure' journal in which to publish his ideas arose from an uncertainty as to their validity (e.g. Wood, 1985, p. 94). Be that as it may, there is some irony in the fact that publication was on Gregory's 'home turf'; he retired as Professor of Geology at the University of Glasgow at the end of September 1929.

Gregory's opinion of the Scotia Arc and its geology had been much influenced by the work of Ferguson on South Georgia. Nevertheless, he maintained the view that the evidence presented was insufficient to determine whether the island formed part of the "mountain loop that must once have connected Patagonia [South America] with Graham Land [Antarctic Peninsula]”, or whether that 'loop' passed west of the island leaving South Georgia as the vestige of a foundered Atlantic continent. This lost landmass formed part of Neumayr's 'Brazil-Ethiopian Continent' or 'Flabellite Land' as it had been designated by Schwarz (1906) based on the distribution of a small Devonian brachiopod then known as Leptocoelia flabellites (Southern Hemisphere examples are now known as Australocoelia palmata). Tyrrell (1915), in a description of the petrography of Ferguson's South Georgia specimens, stressed their similarity to rocks from the South Orkney Islands - as had Pirie (1913) in his unpublished Scotia report - but was equally non-commital with regard to the overall regional structure. However, after reviewing the subsequently collected specimen suites Tyrrell (1918) came down against Suess's 'great loop', preferring that “South Georgia and the South Orkneys are remnants of an ancient continental land which once occupied the South Atlantic”. Pirie (1913, p 8) had also debated the various possible lines of a structural link between South America and the Antarctic Peninsula and found the Falkland Islands particularly problematical. One possibility, he concluded, was that "they are, along with South Georgia and the South Orkneys, fragments of an ancient "Flabellites land”."

Gregory (1922) had illustrated the 'Brazilio-Ethiopian Continent' spanning the South Atlantic, and such thinking carried through to his (1929) Presidential Address to the Geological Society of London, wherein he included South Georgia (but not the South Orkney Islands) within a Devonian 'Flabellites Land' and both South Georgia and the Falkland Islands within a late Palaeozoic 'Gondwanaland' that included the entire 
area of the South Atlantic Ocean (Figures 6a, 6b). Clearly Gregory was not convinced by Du Toit's (1927, 102-103 and figure 7 therein) contemporary reconstruction in which the South Atlantic was eliminated and geological links between Africa and South America were emphasised; the Falkland Islands were notably moved a considerable distance north to align their geology with the structural trends seen in the two, now contiguous continents (Figure 5).

Holtedahl (1929) was also suspicious of continental drift. Writing after the 1927-1928 Norwegian Antarctic Expedition, he stressed the geological similarities of South Georgia and Tierra del Fuego, but eschewed a drift explanation for the Scotia Arc, aligning himself more (1929, p 104) with the views expressed by Gregory (1929) in his Presidential Address. Holtedahl drew comparisons with features in the Northern Hemisphere that he had described previously (Holtedahl 1920) in terms of ocean formation by the subsidence of continental areas. Though stressing his opposition to the permanence of oceanic basins (1920, p. 21) he also made clear his negative view of continental drift in a footnote (1920, p. 24) as follows:

"I shall not enter here into any discussion of the very daring - in my opinion far too daring - hypothesis of Wegener .... according to which the separation of America and Europe was caused by a horizontal movement."

Newman (1995) has pointed out that Holtedahl's (1920) paper (in the American Journal of Science) was the first mention of Wegener's 'displacement hypothesis' in an American periodical but, by 1929, the widespread and emphatic American dismissal of continental drift (Newman 1995; Oreskes 1999) would have reinforced Holtedahl's inclination to reject that process as a solution to the development of the Scotia Arc. Nevertheless, Du Toit (1937, p. 36) listed Holtedahl amongst the geologists sympathetic to the continental drift hypothesis. For the South Atlantic region he might more appropriately have listed Kranck who had worked extensively in Tierra del Fuego, had noted the geological similarities with South Georgia (making specific lithostratigraphical correlations), and explained the origin of the Scotia Arc in terms of a series of lateral movements by South America (Kranck 1934).

Curiously, another paper arising from the 1927-1928 Norwegian Antarctic Expedition was less dismissive of continental drift than Holtedahl's (1929) account. Barth and Holmsen (1939) had enjoyed a decade more than Holtedahl to consider the matter for their paper, which was subtitled as "being a description of rock samples collected by Olaf Holtedahl 1927-1928, and a discussion of their mode of origin”. Though the contribution was primarily an account of petrology and geochemistry, Barth and Holmsen concluded with a short section on the "Origin of the South Antillean Arc". Though admitting that the nature of the tectonic forces involved remained a puzzle, they envisaged an origin by continental drift (Barth and Holmsen 1939, p. 62) - "if we believe, with Wegener, in a single huge continent that split into fragments which drifted apart." Visualising two of those fragments as South America and the Antarctic Peninsula, linked by a narrow isthmus, Barth and Holmsen continued:

"If now this twin continent was drifting westward, then the connecting landbridge, due to its lesser moment of inertia, would lag behind ... The result would be an arcuate ridge pulled out to a large loop that eventually would break up to pieces.”

This is very close to the earlier concept outlined by Wegener (1929) and Holmes (1929). Barth and Holmsen (1939, p, 62) went on metaphorically, perhaps influenced by the state of Europe as they wrote: "The Southern Antilles represent patches of the 
mother-continent torn off and left behind in a foreign environment; they are spoils of war.” But despite the dramatic imagery, Barth and Holmsen concluded rather tamely that "[t]he recognition of this process requires, to a certain extent, a further modification of the theory of the permanence of the continents and ocean basins."

Du Toit (1937) had meanwhile developed his continental drift interpretations and reconstruction of Gondwana in the seminal geological classic Our Wandering Continents. Therein, (1937, figure 7) the Scotia Arc is shown looping into the Palaeozoic 'Samfrau Geosyncline' (Figure 5), a situation influenced by the presumption that Lower Palaeozoic rocks formed at least part of South Georgia. In the accompanying text (pp 195-196) Du Toit linked the origin of the Scotia Arc islands with that of the Falkland Islands, writing:

"Our interpretation views the near-by Falkland Islands as having drifted from some position off the south-western Cape [South Africa]. South Georgia and the South Orkneys could in similar fashion have been derived from the north-east and inferentially from the Samfrau geosyncline.”

It is worth noting that Du Toit's assessment of the Falkland Islands was soundly based. The geological association of the Falklands with South Africa had been established from palaeontological evidence in the late $19^{\text {th }}$ and early $20^{\text {th }}$ centuries, as described by Stone and Rushton (2012). Broader geological links had been discussed by Halle (1911) and, particularly, by Baker (1924) who emphatically adopted a continental drift solution in principle, but did not propose any specific palaeogeography.

\section{The Post-War resurgence of continental drift solutions for the South Atlantic}

The outbreak of the Second World War in 1939 overshadowed any further interest in such long-term issues as continental drift, although geophysical techniques developed for submarine warfare were to prove fundamental to the establishment of plate tectonics theory as the definitive culmination of the continental drift debate. Another outcome of wartime activity that was to have important consequences for geological interpretation in the South Atlantic region went by the code name Operation Tabarin. As described by Dudeney and Walton (2012) this saw the covert establishment of British naval outposts in the South Shetland Islands and northern Graham Land which, at war's end, were transformed into civilian-led, scientific research bases under the auspices of the Falkland Islands Dependencies Survey (FIDS). In the late 1940s two geologists were involved in FIDS Antarctic geological research work who contributed subsequently to the interpretation of the South Atlantic islands and Scotia Arc: J. R. F. Joyce and R. J. Adie.

Joyce (a Captain in the Royal Engineers) spent the 1946 austral winter at the Stonington FIDS base on the Antarctic Peninsula, and then returned to work on his results at Imperial College, London. This led, in 1950, to a presentation at a meeting of the British Association for the Advancement of Science (BAAS), held that year in Birmingham. The BAAS meeting was a wide-ranging affair, but it included a one-day symposium to discuss "The Theory of Continental Drift"; six speakers covered aspects of biogeography and geology. In the published account of his presentation Joyce (1951) utilised a reconstruction of the Gondwana section of Pangaea in which the islands of the Scotia Arc were strung out along that portion of the supercontinental margin formed by South Africa and the Antarctic (Figure 7). He stressed the South 
African associations of the Falkland Islands, and proposed linking the Cretaceous strata of South Georgia with supposedly similar-aged rocks in Mozambique. The present-day spatial arrangement of the islands forming the Scotia Arc was thus seen as a partly original feature, with their arcuate distribution being strongly accentuated as a consequence of continental drift during the break-up of Gondwana. Joyce's main problem was the relatively hostile mood of the BAAS meeting, with opposition to the concept of continental drift led by the eminent geophysicist Professor Harold Jeffreys. His contribution to the BAAS meeting (Jeffreys 1951) was a rather patronising and world-weary dismissal of the continental drift idea since any conceivable mechanism must, he claimed, conflict with the basic physical properties of solids and liquids that "[w]e have all learnt at school" (1951, p 79); he bemoaned the fact that "[t]his is the fourth time that I have taken part in a public discussion of this theory" ( $p$ 80), implying that the time had come to call a halt to speculation. Against this background Joyce (1951, p 87) ended defensively: “The suggestion is therefore made that if Pangaea did in fact exist then this new organisation of continental masses and island arcs at the opening of the Palaeozoic era is more in accord with the known data" italics as in original.

Adie spent three austral winters, 1947 to 1949, at the Hope Bay and Stonington FIDS bases; the third winter was unplanned and came about when ice conditions prevented relief of the Stonington base. He was a South African geologist who had graduated from the University of Natal, from a geology department led by Professor Lester King. Alexander Du Toit had died in 1948, but the cause of continental drift had found a new champion in King. He had proposed a solution to biogeographical problems in Australasia based on continental drift (King 1944) and after a proselytising lecture tour for the American Association of Petroleum Geologists wrote (King 1953, p 2163), that "[t]he subject is apparently little taught in American colleges and many in the audiences professed ignorance and a desire for information on which they could base a judgement for themselves. A new spirit seemed to be abroad of impartial enquiry and broad outlook.” King's response was unequivocal, with his 1953 paper carrying the title Necessity for Continental Drift. Therein, King reinforced Du Toit's trans-Atlantic correlations but also highlighted the geological associations from the east side of Africa into Antarctica, continents that had been only tentatively juxtaposed by Du Toit in his 1937 Gondwana reconstruction (Figure 5). But for the South Atlantic the most significant aspects of King's paper appeared in a footnote and an appendix. The footnote (King 1953, p 2169) expressed King's delight at the results achieved in South America and the Falkland Islands by two of his students, D.L. Niddrie and R.J. Adie. In the preceding text King noted that " $[t]$ he evidence of the writer's own students from South Africa who have worked in the Falkland Islands and in South America is that they were perfectly at home in the various formations (see Appendix), which to them were similar in type, in sequence, and in fossils.” The Appendix to which King referred was written by Niddrie (1953) and described the geology of the Falkland Islands, stressing the South African correlations. The footnote also recorded that "R.J. Adie is publishing his opinions separately".

Adie's paper was most probably in press when King wrote, since it appeared late in 1952. In it, Adie proposed an even more radical solution to the mismatched regional geology of the Falkland Islands than had been envisaged by Du Toit. In a remarkably prescient contribution, Adie (1952) used the alignment of structural and 
sedimentological trends to support his proposal that the Falklands had been rotated by $180^{\circ}$ from an original position adjacent to the east coast of South Africa (Figure 8 inset). This solution to the enigma of Falklands geology was completely neglected by the geological mainstream until it was 'rediscovered' in terms of microplate rotation (Mitchell et al. 1986) late in the plate tectonic revolution. It is now widely (although not universally) accepted in principle. Adie had spent time in the Falkland Islands in 1950 during his journey back to Britain from the Antarctic and a fossil collection that he made at the time is held by the Sedgwick Museum, Cambridge. It is instructive that in his manuscript notes accompanying the fossils, Adie confirms King's assessment that he was geologically 'at home' by using the South African stratigraphical term 'Bokkeveld Series' to describe the fossiliferous Falklands beds now known, within the West Falkland Group, as the Fox Bay Formation.

However, despite drawing attention to the African associations of the Falkland Islands, King omitted them entirely from his Gondwana reconstruction (1953, figure 1 therein) which is the basis for Figure 8 of this paper. His dilemma is clear. In his Gondwana reconstruction the outline of the' Karoo Basin' is shown spanning South America, South Africa and Antarctica. To include the Falklands 'Karoo' component (the Lafonia Group), as Du Toit $(1927,1937)$ had realised, the basin must either be extended to unreasonable proportions, or the Falklands archipelago must be moved a considerable distance. Was King unaware of Adie's 'in press' solution, or did he think it uncomfortably too radical? Perhaps there was a good reason why "R. J. Adie is publishing his opinions separately”. King's continuing uncertainty may be the reason for the omission of any mention of the Falkland Islands, or Adie (1952), in his subsequent and otherwise comprehensive review (King 1958) of the correlations between South African and South American stratigraphy, and their compelling compatibility with Gondwana reconstructions. Whatever the reason, the omission still seems odd in view of King's previously expressed enthusiasm for Falkland Islands geology.

It is interesting to note that in his Pangaea/Gondwana reconstruction for the BAAS meeting (Figure 7), Joyce (1951) had placed the Falkland Islands to the south-east of South Africa, rather than follow Du Toit's $(1927,1937)$ positioning of them on the west side of Africa. Joyce had passed through the Falklands when travelling to and from the Antarctic Peninsula, and spent long enough there to carry out some research work on the local periglacial boulder fields, so was most probably familiar with the geology. In addition, it is likely that Joyce and Adie, two Antarctic veterans of the FIDS Stonington base, would have met and discussed their findings when Adie got back to Britain in 1950 - although Adie was writing-up in Cambridge whereas Joyce was based in London. If Adie's Falkland Islands observations influenced Joyce's reconstruction of Pangaea it was fortunate, since Du Toit's positioning of the islands between South Africa and South America was singled out for particular criticism at the Birmingham BAAS meeting (Umbgrove 1951, p 67). Alternatively, it is possible that Joyce's reconstruction (the preparation of which he describes in detail in his 1951 paper) catalysed Adie's Falkland Islands interpretation. But whilst some positive feedback between the pair seems probable, there is also evidence for a more strained relationship. After completing a University of London $\mathrm{PhD}$ thesis, and with the exception of his BAAS presentation, Joyce published nothing more on his Antarctic results. In contrast, Adie published extensively but referred only once to Joyce's contribution, and then only in a rather dismissive fashion. In a review of geological 
investigations in the Falkland Islands Dependencies Adie (1958, p.10) noted that "J.R.F. Joyce collected rocks from the immediate vicinity of the [Stonington] station and Neny Fjord, but his sledging on the plateau was relatively unproductive because of the sparsity of outcrops.”

Through the 1950s, the geology of the islands forming the Scotia Arc became better known. Trendall's field work on South Georgia during the 1951-52 and 1952-53 austral summers led to the publication of two FIDS scientific reports (Trendall 1953, 1959). The 1953 report includes a speculative correlation of the wacke sandstone successions with superficially similar successions in the Antarctic Peninsula and the South Orkney Islands. At that time, regional stratigraphic correlation was much influenced by the supposed graptolite from the South Orkney Islands (Pirie 1905) and, as already noted, it was thought possible that the unfossiliferous Sandebugten Formation of South Georgia might correlate with the apparently Lower Palaeozoic rocks of the South Orkneys.

The 'graptolite' from the South Orkney Islands had been confirmed as such by the established palaeontological authorities Gertrude Elles and Ben Peach, the latter also identifying phyllocarid remains (Pirie 1905, 1913). With this pedigree the fossils went unquestioned for 50 years, apparently supported by another discovery of a 'graptolite' by Argentine geologists, as reported by Cordini (1955) and Thomson (1977).

However, when Pirie's specimens (National Museum of Scotland specimen numbers 1954.2.28 and 29) were re-examined by the Birmingham University palaeontologist (and graptolite specialist) Isles Strachan he demurred, as quoted by Adie (1957b, p. 22): "The fragmentary specimens from the South Orkney Islands are extremely poorly preserved. No thecae can be seen on the supposed graptolite stipes and the markings on the other organic fragments can be explained in several ways. There is no positive evidence for an Ordovician-Silurian age for the shales although, of course, the specimens can be interpreted to agree with such an age. They could, however, equally well be identified as plant fragments and assigned to the Carboniferous.” It took some time for this reassessment to become established with, for example, King and Downard (1964) still citing the graptolitic evidence for a Lower Palaeozoic age, curiously enough in a conference volume edited by Adie. Eventually, the supposedly graptolitic rocks yielded Triassic conodonts and radiolaria (Dalziel 1979; Dalziel et al. 1981).

Trendall's second report was published in 1959. Adie became FIDS Chief Geologist in 1956 and would have been involved in its scientific editing, so it is not surprising that following the fall from grace of the South Orkneys 'graptolite', Trendall (1959) presented a revised stratigraphy for South Georgia. Therein, despite remaining uncertainties, the volcaniclastic Cumberland Bay Formation, and the quartzofeldspathic Sandebugten Formation were proposed as possible facies variations within a single Mesozoic succession, an interpretation supported by much subsequent work (see bibliographies in Macdonald et al. 1987 and Curtis and Riley 2011).

Whilst Trendall worked in South Georgia, FIDS geologists were exploring the South Orkney and South Shetland archipelagos farther south, and two of them, D. H. Matthews and D. D. Hawkes, attempted to fit their observations into a wider geological interpretation of the Scotia Arc. The uncertainties imposed on their attempts at 'pre-drift' reconstructions of the Scotia Arc are well exemplified by the 
fact that a geological description of in situ specimens from Shag Rocks (Figure 1) was not published until 1982, based on greenschist-facies metamorphic rocks collected in 1974 (Tanner 1982). Prior to that, the only geological information available for the Shag Rocks continental block derived from similar schistose rocks dredged from the sea floor in 1930 and described by Tyrrell (1945).

Matthews spent the 1956 austral winter at the Signy Island FIDS base in the South Orkney Islands and in 1959, by then at the University of Cambridge, he published an assessment of the Scotia Arc utilising the sparse bathymetric and marine geophysical data that were then available. That paper (Matthews 1959) presents two alternatives: either the islands of the Scotia Arc represented fragments of a laterally disrupted continental mass, or they must be the highest parts of a mostly submerged continental block underlying most of the Scotia Sea. Citing Adie (1952) he noted that continental drift was "an attractive hypothesis" to apply to the geological situation of the Falkland Islands, but found the Scotia Arc altogether less tractable. If the islands were disrupted fragments, and derived as envisaged by Barth and Holmsen (1939) then breaks would be expected in the submarine ridges linking the islands; Matthews saw little evidence for such breaks, albeit the available bathymetric data was sparse.

Conversely, if continental crust underlay the Scotia Sea, it would be associated with a large gravity anomaly; again, supporting evidence was not forthcoming. One complicating factor stressed by Matthews, reiterating a point raised by several previous workers, was the presence of thick clastic successions, in South Georgia and the South Orkney Islands, which required to have been deposited in proximity to a continental provenance. In a conclusion to his 1959 paper that he admitted was unsatisfactory, Matthews was forced to speculate that the Scotia Sea and Arc represented some kind of transition between continental and oceanic crust. However, from this beginning, Matthews' marine geology interpretations blossomed and only a few years later he contributed to one of the seminal papers of the plate tectonic revolution (Vine and Matthews 1963) that explained the pattern of linear magnetic anomalies distributed symmetrically across oceanic spreading ridges.

Hawkes worked on Deception Island, South Shetlands, during the 1957-58 austral summer and subsequently published an interpretation of the structure of the Scotia Arc that returned to the concept of the disruption, by continental drift, of an original isthmus connecting Patagonia and Graham Land (Hawkes 1962). However, whereas Holmes (1929) and Barth and Holmsen (1939) had envisaged westward drift, with the isthmus breaking up to leave behind the islands of the Scotia Arc as abandoned relicts, Hawkes saw the islands as being driven eastwards. Starting with a linear continental connection between Patagonia and Graham Land, Hawkes proposed that an advance of 'Pacific' crust forced the break-up and the progressive eastward drift of the Scotia Arc islands (Figure 9). A succession of island arcs migrated eastward as part of the development of the Scotia Sea which, like Matthews, Hawkes thought of as in some way transitional between oceanic and continental states. The pre-drift, 'linear' reconstruction by Hawkes presaged the subsequently influential, rectilinear models of the early plate-tectonic era, such as that published by Dalziel and Elliot (1971). Hawkes' exposition of the Scotia Arc's origins had been guaranteed a wide audience when it was reproduced by Holmes (1965) as figure 873 in the second edition of his classic text book "Principles of Physical Geology".

\section{South Georgia, the Falkland Islands and plate tectonics}


The rapid passage in American opinion, from near-universal hostility towards continental drift to an all-embracing enthusiasm for plate tectonics, has been analysed in great detail by, for example, Newman (1995) and Oreskes (1999). European attitudes towards continental drift were perhaps more ambivalent, but there was little unequivocal support for the phenomenon in the first half of the $20^{\text {th }}$ century; reviews of the subsequent intellectual transition towards plate tectonics from a British perspective have been provided by Hallam (1973) and Wood (1985). Things were very different in the Southern Hemisphere, where Du Toit and King enjoyed an African vantage point in the centre of Gondwana, whence continental drift seemed obvious and undeniable. Their frustrations at the perceived parochialism of their northern counterparts is noted by Oreskes (1999, p. 296) who cites correspondence between the two South Africans.

Now, although the mechanism of plate tectonics enjoys consensus support, and the geology of the South Atlantic islands is well-established, there is still debate over the original relationships of the islands, and the route by which their current configuration (Figure 1) was achieved. In no small measure this arises from the space problem encountered in Gondwana reconstructions that attempted to maintain the Antarctic Peninsula in its current relationship with East Antarctica. Different solutions have, at different times, required overlap of the Peninsula with South Africa, the Falkland Plateau and South America; some of these issues are summarised by Dalziel and Elliot (1971) and by Thomson and Vaughan (2005). Breaking the Peninsula into a number of independent microplates afforded greater flexibility, as in the view summarised by Dalziel et al. (2013). Therein, South Georgia and other microcontinental blocks originated at the Pacific margin of Gondwana and thence drifted eastward relative to South America and the Antarctic Peninsula following disruption of an original continental link between those two continents. In alternative reconstructions, for example that by Harrison et al. (1979) the Antarctic Peninsula was removed initially to the west of South America before relative movements between them established an approximately linear relationship that could then be disrupted by eastward drift of fragments such as South Georgia. More recently, with a fragmented Antarctic Peninsula lying originally to the west of South America, but concerned by the length of eastward drift required thereafter to position South Georgia, Eagles (2010) has proposed a reconstruction wherein South Georgia formed as part of a Gondwana margin that swung eastward towards South Africa. Debate at this level of geotectonics seems likely to continue.

And what of South Georgia's erstwhile companions in Flabellites Land, the Falkland Islands? They saw the early appreciation of the advantages of a continental drift 'displacement theory' - interpretation by Baker (1924), followed by the pre-Atlantic reconstruction by Du Toit $(1927,1937)$ in which the islands were moved significantly northwards. With hindsight there is some irony in Baker's only concern (1924, p. 30) - "[a] damaging criticism of the views of Wegener which has been put forward by Dr. Harold Jeffreys is that the physical causes that Wegener offers for the migration of continents are entirely inadequate.” Twenty-five years later, Professor Jeffreys, by then pre-eminent in British geophysics, had undermined Joyce's attempt to interpret the Scotia Arc in terms of continental drift at the 1950 meeting of the British Association for the Advancement of Science (Jeffreys 1951; Joyce 1951). Nevertheless, this event was soon followed by the remarkably prescient though 
generally neglected, continental drift interpretation of the Falkland Islands' origin (off the east coast of South Africa) by Adie (1952); the interpretation was ultimately repackaged as a rotated microplate by Mitchell et al. (1986). Thereafter, a rotated Falkland microplate was commonly included in schematic representations of Gondwana break-up (e.g. Marshall 1994; Storey et al. 1999) but some reconstructions still omit the Falkland Islands. With the government of Argentina determinedly maintaining a claim to the Falkland Islands (as Las Islas Malvinas) this may possibly arise as much from political expediency as from geological complexity. Perhaps for that same reason, Dalziel et al. (2013) prefer 'Lafonian microplate' to 'Falklands microplate'.

But despite the compelling evidence for rotation of a Falklands microplate, arising from comparisons of onshore geology and modelling of palaeomagnetic data from the Mesozoic dykes (Taylor and Shaw 1989), the contrary view must also be acknowledged. The data generated by the hydrocarbons exploration programmes that are currently active around the Falkland Islands apparently provide no evidence in support of the rotational model. Instead they are more readily reconciled with a Gondwana break-up in which the archipelago remains part of a fixed Falkland Plateau extending from the South American margin (e.g. Richards et al. 1996; Lawrence et al. 1999), albeit one that has undergone much extension. More recently, modelling of the linear aeromagnetic anomalies associated with the Falkland Islands onshore dykes by Stone et al. (2009) has supported the rotational interpretation, whereas Ramos (2008) has reiterated Borrello's (1963) correlation of the Falklands basement (Cape Meredith Complex) with the Proterozoic Deseado massif of Patagonia. The proponents of a non-rotational interpretation question the veracity of the existing palaeomagnetic data, and the matter seems unlikely to be settled without additional, unequivocal results from the Falkland Islands dykes.

As the plate tectonic revolution gathered pace, large-scale, global reviews by several of the leading partisans touched on the South Atlantic, usually coupling an interpretation of the Scotia Arc with the Caribbean/Antillean arc much farther to the north. Wilson (1966) introduced the concept of transform faults defining the North and South Scotia Ridges by means of an ingenious analogy to ice rafting, but for the most part these contributions brought a new-found scientific respectability to ideas long-neglected as unfeasible but now independently rediscovered. For example, Hamilton (1966, p. 178) summed-up his assessment in the abstract to his paper as follows: "If the continents [North and South America and Antarctica] are regarded as having drifted westward into the Pacific Ocean basin, then the two arcs can be pictured as formed by the disruption of the narrow bridges, which lagged behind the continents." This process is illustrated (Figure 10a) by Hamilton in the un-numbered figure accompanying his paper, but is essentially the circumstance described almost 30 years earlier by Barth and Holmsen (1939), which in turn followed Wegener (1929, pp 94-95) and Holmes (1929, pp 594-595) - all three contributions were apparently overlooked by Hamilton. As in the earlier debate, the proposal that the Scotia Arc originated by means of westward continental drift was soon followed by a proposal invoking eastward drift. Moores (1970) developed a model to explain Mesozoic orogenies at the western margins of North and South America. He envisaged a Pacific island arc system colliding with the continental margins, resulting in orogeny, but that " $[w]$ here no continent was present (as between North and South America and south of South America), the remnants of this island arc system simply 
continued migration, forming the Caribbean and Scotian (sic) Seas” (Moores 1970, caption to figure 6, p. 842). Unsaid but implied (Figure 10b) would be the detachment by the eastward-migrating 'Scotian Sea arc' of continental blocks from the South American and Antarctic Peninsula continental terminations, which were then strung-out to form the North and South Scotia Ridges. Moores' model in respect of the Scotia Arc (a very minor component of the whole paper it must be stressed) is not that far removed from the situation envisaged by Hawkes (1962) wherein a thin, rectilinear continental connection between South America and the Antarctic Peninsula was disrupted by "an eastward advance of the Pacific crust" (Hawkes 1962, abstract); Moores did not cite Hawkes’ paper which had also envisaged island arcs migrating eastward.

\section{Epilogue}

From a Northern Hemisphere perspective, the geological zeitgeist changed profoundly over the course of a few years in the late 1960s. From the Southern Hemisphere the revolution appeared rather less radical; there it was more the development of an adequate mechanism to explain the clearly perceived geological relationships. As the geology of the South Atlantic islands become established, and despite the prevailing attitudes elsewhere, once Wegener had articulated the theory there was always a body of opinion that looked towards continental drift as an explanation for their geological relationships. The views of geologists based in the north but working in the south slowly became more influential, and it is notable that several of the key figures in the broader debate began to cite the examples of the Scotia Arc and/or the Falkland Islands as compelling evidence for continental drift, reinvented as plate tectonics. That would not have been possible but for the pioneering, field-based geological researchers who worked in the region, in arduous and often dangerous circumstances. This review is dedicated to those largely unsung scientific adventurers.

\section{Acknowledgements}

This paper is published by permission of the Executive Director, British Geological Survey (NERC). It has benefitted greatly from the informed comments of Bruce Mair on its earlier iterations, and the helpfully focussed efforts of the reviewers, Don Aldiss and Mike Thomson; my sincere thanks go to all three. I am also grateful for the editorial attention of Colin Prosser, whilst the quality of the figures is largely due to the skill of Craig Woodward. I have been privileged to enjoy extensive geological field-work in both South Georgia and the Falkland Islands, and owe a sincere debt of gratitude to all those who have made it possible.

\section{References}

Adie, R.J. 1952. The position of the Falkland Islands in a reconstruction of Gondwanaland. Geological Magazine, 89, 401-410.

Adie, R.J. 1957a. Geological investigations in the Falkland Island Dependencies before 1940. The Polar Record. 8, 502-513. 
Adie, R.J. 1957b. The petrology of Graham Land: III. Metamorphic rocks of the Trinity Peninsula Series. Falkland Islands Dependencies Survey Scientific Report, 20, $26 \mathrm{pp}$.

Adie, R.J. 1958. Geological investigations in the Falkland Island Dependencies since 1940. The Polar Record. 9, 3-17.

Aldiss, D.T., Edwards, E.J. 1998. Geology of the Falkland Islands. Solid Geology 1:250 000. Two sheets, East and West. British Geological Survey for Falkland Islands Government.

Aldiss, D.T., Edwards, E.J. 1999. The Geology of the Falkland Islands. British Geological Survey Technical Report, WC/99/10. 135 pp.

Andersson, J.G. 1907a. Contributions to the geology of the Falkland Islands. Wissenschaftliche Ergebnisse der Schwedischen Sudpolar-expedition 1901-1903, 3, Lieferung 2, 38 pp.

Andersson, J.G. 1907b. On the principal results of the Swedish Antarctic Expedition. Compte Rendu 10ème Congrès géologique international, Mexico 1906, 10. 723-733.

Arçtowski, H. 1895. Observations sur l'intérêt que présente l'exploration géologique des Terres Australes. Bulletin Société géologique de France. $3^{\mathrm{e}}$ série, 23, 589-591.

Baker, H.A. 1924. Final Report on Geological Investigations in the Falkland Islands, 1920-1922. Government Printer, Stanley. 38 pp, map, cross-section and 18 figures.

Barrow, J. 1831. Introductory note to an Account of the Island of Deception, one of the New Shetland Isles. Journal of the Royal Geographical Society, London, 1, 62.

Barth, T.F.W., Holmsen, P. 1939. Rocks from the Antarctandes and the Southern Antilles. Scientific Results of the Norwegian Antarctic Expedition 1927-1928, 18. I Kommisjon Hos Jacob Dybwad, Oslo. 64 pp + 4 plates.

Bellingshausen, T. von. 1831. English translation: Debenham, F. (ed.) 1945. The Voyage of Captain Bellingshausen to the Antarctic Seas, 1819-1821. The Hakluyt Society, London. 1, xxx and 1-259; 2, viii and 260-474.

Borrello, A.V. 1963. Sobre la Geologia de las Islas Malvinas. Ediciones Culturales Argentinas, Ministerio de Educacion y Justica, Buenos Aires. 70 pp + fold-out map.

Bruce, W.S. 1905. Bathymetric Survey of the South Atlantic Ocean and Weddell Sea. Scottish Geographical Magazine, 21, 402-412 + 2 maps.

Carse, V.D. 1959. The Survey of South Georgia, 1951-57. Geographical Journal, 125, 20-37.

Clarke, J.M. 1913. Fósseis Devonianos do Paraná. Monographia do Serviço Geológico y Mineralógico do Brasil, 1, 353 pp. 
Cordini, I.R. 1955. Contribución al conocimiento del sector Antártico Argentine. Publicaciónes del Instituto Antártico Argentino, 1. 277 pp.

Curtis, M.L., Riley, T.R. 2011. Geological Map of South Georgia (1:250 000 scale). BAS GEOMAP 2 Series, Sheet 4, British Antarctic Survey, Cambridge, UK.

Dalziel, I.W.D. 1979. The mythical graptolites of the South Orkney Islands. The Edinburgh Geologist, 6, 2-9.

Dalziel, I.W.D., Elliot, D.H. 1971. Evolution of the Scotia Arc. Nature, London, 233, 246-252.

Dalziel, I.W.D., Dott, R.H., Winn, R.D., Bruhn, R.L. 1975. Tectonic Relations of South Georgia Island to the Southernmost Andes. Geological Society of America Bulletin, 86, 1034-1040.

Dalziel, I.W.D., Elliot, D.H., Jones, D.L., Thomson, J.W., Thomson, M.R.A., Wells, N.A., Zinsmeister, W.J. 1981. The geological significance of some Triassic microfossils from the South Orkney Islands, Scotia Ridge. Geological Magazine, 118, 15-25.

Dalziel, I.W.D., Lawver, L.A., Norton, I.O., Gahagan, L.M. 2013. The Scotia Arc: Genesis, Evolution, Global Significance. Annual Review of Earth and Planetary Science, 41, 767-793.

Darwin, C.R. 1846. On the geology of the Falkland Islands. Quarterly Journal of the Geological Society of London, 2, 267-274.

Douglas, G.V. 1930. Topography and geology of South Georgia. British Museum (Natural History) Report on the Geological Collections made during the voyage of the "Quest" on the Shackleton-Rowett Expedition to the South Atlantic \& Weddell Sea in 1921-22. Trustees of the British Museum, London. 4-24.

Dudeney, J.R., Walton, D.W.H. 2012. From Scotia to 'Operation Tabarin’: developing British policy for Antarctica. The Polar Record, 48, 342-360.

Du Toit, A.L. 1927. A geological comparison of South America and South Africa (with a palaeontological contribution by F.R. Cowper Reed). Carnegie Institution of Washington, Washington. 158 pp, 16 plates and folded map insert.

Du Toit, A.L. 1937. Our Wandering Continents. Oliver and Boyd, Edinburgh and London, 366 pp.

Eagles, G. 2010. South Georgia and Gondwana's Pacific Margin: Lost in translation? Journal of South American Earth Sciences, 30, 65-70.

Ferguson, D. 1915. Geological observations in South Georgia. Transactions of the Royal Society of Edinburgh, 50, 797-814, 10 plates. 
Greenway, M.E. 1972. The geology of the Falkland Islands. British Antarctic Survey Scientific Reports, 76, 42 pp.

Gregory, J.W. 1901. The work of the National Antarctic Expedition. Nature, London, 63, 609-612.

Gregory, J.W. 1915. The Geological Relations and Some Fossils of South Georgia. Transactions of the Royal Society of Edinburgh, 50, 817-822 + 2 plates.

Gregory, J.W. 1922. Supplementary Note on the Geology of Benguella in relation to its Cephalopods and the History of the South Atlantic. Transactions of the Royal Society of Edinburgh, 53, 161-163.

Gregory, J.W. 1929. The Geological History of the Atlantic Ocean. Quarterly Journal of the Geological Society, London, 85, Proceedings lxviii-cxxii.

Hallam, A. 1973. A Revolution in the Earth Sciences. Oxford University Press, Oxford. 127 pp.

Halle, T.G. 1911. On the geological structure and history of the Falkland Islands. Bulletin of the Geological Institution of the University of Uppsala, 11, 115-229.

Hamilton, W. 1966. Formation of the Scotia and Caribbean arcs. Geological Survey of Canada Paper, 66-15, 178-185.

Harrison, C.G.A., Barron, E.J., Hay, W.W. 1979. Mesozoic evolution of the Antarctic Peninsula and the southern Andes. Geology, 7, 374-378.

Hattersley-Smith, G. 1980. The History of Place-names in the Falkland Islands Dependencies (South Georgia and the South Sandwich Islands). British Antarctic Survey Scientific Reports, 101, 112 pp.

Hawkes, D.D. 1962. The Structure of the Scotia Arc. Geological Magazine, 99, 8591.

Heim, F. 1912. Geologische Beobachtungen über Süd-Georgien. Zeitschrift der Gesellschaft für Erdkunde zu Berlin, 6, 451-456.

Herdman, H.F.P. 1932. Report on soundings taken during the Discovery Investigations, 1926-1932. Discovery Reports, 6, 205-236. Cambridge.

Holmes, A. 1929. Radioactivity and Earth Movements. Transactions of the Geological Society of Glasgow, 18, 559-606.

Holmes, A. 1965. Principles of Physical Geology ( ${ }^{\text {nd }}$ edition). Nelson, London and Edinburgh. 1288 pp.

Holtedahl, O. 1920. Paleogeography and Diastrophism in the Atlantic-Arctic Region during Paleozoic Time. American Journal of Science, 49, 1-25. 
Holtedahl, O. 1929. On the Geology and Physiography of some Antarctic and SubAntarctic Islands. Scientific Results of the Norwegian Antarctic Expedition 19271928, 3. I Kommisjon Hos Jacob Dybwad, Oslo. 172 pp + 52 plates.

Jeffreys, H. 1951. Mechanical Aspects of Continental Drift and Alternative Theories. The Advancement of Science, 8, 79-80.

Joyce, J.R.F. 1951. The Relation of the Scotia Arc to Pangaea. The Advancement of Science, 8, 82-88.

Keidel, J. 1916. La Geología de las Sierras de la Provincia de Buenos Aires y sus Relaciones con las Montañas de Sud Africa y los Andes. Annales del Ministerio de Agricultura de la Nación, Sección Geolgía, Mineralogía y Minería, 11 (3), 5-78.

King, L.C. 1944. On Palaeogeography. South African Geographical Journal, 26, 113.

King, L.C. 1953. Necessity for Continental Drift. Bulletin of the American Association of Petroleum Geologists, 37, 2163-2177.

King, L.C. 1958. Basic Palaeogeography of Gondwanaland during the Late Palaeozoic and Mesozoic Eras. Quarterly Journal of the Geological Society, London, 114, 47-70.

King, L.C., Downard, T. W. 1964. Importance of Antarctica in the hypothesis of continental drift. In: Adie, R. J. (ed.) Antarctic Geology. North Holland Publishing Co., Amsterdam. 727-735.

Klutschak, H.W. 1881. Ein Besuch auf Süd Georgien. English translation by Boumphrey, R.S. 1967. A Visit to South Georgia. British Antarctic Survey Bulletin, 12, 85-92.

Kranck, E.H. 1934. The South Antillean Ridge. Bulletin de la Commission Géologique de Finlande, 104, 99-103.

Lawrence, S.R., Johnson, M., Tubb, S.R., Marshallsea, S.J. 1999. Tectonostratigraphic evolution of the North Falkland region. In: Cameron, N.R., Bate, R.H., Clure, V.S. (eds) The Oil and Gas Habitats of the South Atlantic. Geological Society, London, Special Publications, 153, 409-424.

Leake, B.E. 2011. The Life and Work of Professor J. W. Gregory FRS (1864-1932): Geologist, Writer and Explorer. Geological Society, London, Memoirs, 34, 234 pp.

Macdonald, D.I.M., Storey, B. C., Thomson, J. W. 1987. South Georgia. BAS GEOMAP Series, Sheet 1, 1:250 000, Geological map and supplementary text, 63 pp. Cambridge, British Antarctic Survey.

Marshall, J.E.A. 1994. The Falkland Islands: a key element in Gondwana palaeogeography. Tectonics, 13, 499-514. 
Matthews, D.H. 1959. Aspects of the Geology of the Scotia Arc. Geological Magazine, 96, 425-441.

Mitchell, C., Taylor, G.K., Cox, K.G., Shaw, J. 1986. Are the Falkland Islands a rotated microplate? Nature, 319, 131-134.

Moores, E. 1970. Ultramafics and Orogeny, with Models of the US Cordillera and the Tethys. Nature, London, 228, 837-842.

Morris, J., Sharpe, D. 1846. Description of eight species of brachiopodous shells from the Palaeozoic rocks of the Falkland Islands. Quarterly Journal of the Geological Society of London, 2, 274-278.

Newman, R.P. 1995. American Intransigence: The Rejection of Continental Drift in the Great Debates of the 1920s. Earth Sciences History, 14, 62-83.

Niddrie, D.L. 1953. Falkland Islands (Appendix to King 1953). Bulletin of the American Association of Petroleum Geologists, 37, 2175-2177.

Nordenskjöld, O., Andersson, J.G. 1905. Antarctica or Two years amongst the ice of the South Pole. Hurst and Blackett, London. 608 pp.

Oreskes, N. 1999. The Rejection of Continental Drift. Oxford University Press, New York and Oxford, xi + 420 pp.

Pirie, J.H.H. 1905. On the Graptolite-bearing Rocks of the South Orkneys. Proceedings of the Royal Society of Edinburgh, 25, 463-470.

Pirie, J.H.H. 1913. Geology of the South Orkneys. Galley proof (11 pp) of a contribution intended for the unpublished Scottish National Antarctic Expedition Scientific Report, 8. Held by the British Antarctic Survey, Cambridge.

Ramos, V.A. 2008. Patagonia: A Palaeozoic continent adrift? Journal of South American Earth Sciences, Vol. 26, 235-251.

Richards, P.C., Gatliff, R.W., Quinn, M.F., Williamson, J.P., Fannin, N. G. T. 1996. The geological evolution of the Falkland Islands continental shelf. In: Storey, B.C., King, E.C., Livermore, R.A. (eds) Weddell Sea Tectonics and Gondwana Break-up, Geological Society, London, Special Publications, 108, 105-128.

Richards, P.C., Stone, P., Kimbell, G.S., McIntosh, W.C., Phillips, E.R. 2013. Mesozoic magmatism in the Falkland Islands (South Atlantic) and their offshore sedimentary basins.Journal of Petroleum Geology, 36, 61-74.

Schuchert, C. 1932. Gondwana Land Bridges. Bulletin of the Geological Society of America, 43, 875-916.

Schwarz, E.H.L. 1906. The former land connection between Africa and South America. Journal of Geology, 14, 81-90. 
Sharpe, D., Salter, J.W. 1856. Description of Palaeozoic fossils from South Africa.

Transactions of the Geological Society of London, Series 2, 7, 203-225.

Stone, P. 1980. The Geology of South Georgia: IV. Barff Peninsula and Royal Bay areas. British Antarctic Survey Scientific Reports, 96, 45 pp + 8 plates.

Stone, P., Faithfull, J. 2013. The mineral prospecting expeditions to the South Atlantic islands and Antarctic Peninsula region made by the Scottish geologist David Ferguson, 1912-1914. Scottish Journal of Geology, 49, 59-77.

Stone, P., Rushton, A. W. A. 2012. The pedigree and influence of fossil collections from the Falkland Islands: From Charles Darwin to continental drift. Proceedings of the Geologists' Association, 123, 520-532.

Stone, P., Rushton, A. W. A. 2013. Charles Darwin, Bartholomew Sulivan and the geology of the Falkland Islands: unfinished business from an asymmetric partnership. Earth Sciences History, 32, 156-185.

Stone, P., Aldiss, D. T., Edwards, E. J. 2005. Rocks and Fossils of the Falkland Islands. British Geological Survey for Department of Mineral Resources, Falkland Islands Government. Keyworth, Nottingham. 60 pp.

Stone, P., Kimbell, G.S., Richards, P.C. 2009. Rotation of the Falklands microplate reassessed after recognition of discrete Jurassic and Cretaceous dyke swarms.

Petroleum Geoscience, 15, 279-287.

Storey, B.C., Curtis, M.L., Ferris, J.K., Hunter, M.A., Livermore, R.A. 1999.

Reconstruction and break-out model for the Falkland Islands within Gondwana. Journal of African Earth Sciences, 29, 153-163.

Suess, E. 1909. The Face of the Earth. (English translation of Das Antlitz der Erde by H. B. C. Sollas), 4. The Clarendon Press, Oxford. 673 pp.

Tanner, P.W.G. 1982. Geology of Shag Rocks, part of a continental block on the North Scotia Ridge, and possible regional correlations. British Antarctic Survey Bulletin, 51, 125-136.

Taylor, G.K., Shaw, J. 1989. The Falkland Islands: New palaeomagnetic data and their origin as a displaced terrane from southern Africa. In: Hillhouse, J.W. (ed.) Deep structure and past kinematics of accreted terranes. American Geophysical Union (AGU) Geophysical Monographs, 50, 59-72.

Thomson, M.R.A. 1977. An annotated bibliography of the paleontology of Lesser Antarctica and the Scotia Ridge. New Zealand Journal of Geology and Geophysics, 20, 865-904.

Thomson, M.R.A., Vaughan, A.P.M. 2005. The role of Antarctica in the development of plate tectonic theories: from Scott to the present. Archives of Natural History, 32, 362-393. 
Thürach, H. 1890. Geognostische Bewchriebung der Insel Sud-Georgien. Die Internationale Polarforschung 1882-1883. Die deutschen Expeditionen und ihre Ergebnisse. 2: Beschreibende Naturwissenschaften in einzelnen Abhandlung. Hamburg. 107-164.

Trendall, A.F. 1953. The Geology of South Georgia: I. Falkland Islands Dependencies Survey Scientific Reports, No. 7, 26 pp, 2 plates, fold-out map.

Trendall, A.F. 1959. The Geology of South Georgia: II. Falkland Islands Dependencies Survey Scientific Reports, No. 19, 47 pp, 5 plates, fold-out map.

Tyrrell, G.W. 1915. The Petrology of South Georgia. Transactions of the Royal Society of Edinburgh, 50, 823-836, 1 plate.

Tyrrell, G.W. 1916. Further notes on the petrography of South Georgia. Geological Magazine, Decade 6, 3, 435-441.

Tyrrell, G.W. 1918. Additional notes on the petrography of South Georgia. Geological Magazine, Decade 6, 5, 483-489.

Tyrrell, G.W. 1930. The petrography and geology of South Georgia. British Museum (Natural History) Report on the Geological Collections made during the voyage of the "Quest" on the Shackleton-Rowett Expedition to the South Atlantic \& Weddell Sea in 1921-22. London: Trustees of the British Museum. 28-54.

Tyrrell, G.W. 1945. Report on rocks from West Antarctica and the Scotia Arc. Discovery Reports, 23, 37-102. Cambridge.

Umbgrove, J.H.F. 1951. The Case for the Crust-substratum theory. The Advancement of Science, 8, 67-71.

Vine, F.J., Matthews, D.H. 1963. Magnetic anomalies over oceanic ridges. Nature, London, 199, 947-949.

Wegener, A. 1912. Die Entstehung der Kontinente. Geologische Rundschau, 3, 276292.

Wegener, A. 1915. Die Entstehung der Kontinente und Ozeane. Friedrich Vieweg \& Sohn, Braunschweig.

Wegener, A. 1922. Die Ehtstehung der Kontinente und Ozeane (3rd edition). Friedrich Vieweg \& Sohn, Braunschweig. English translation by Skerl, J. G. A. Published as The Origin of Continents and Oceans by Methuen, London. 1924.

Wegener, A. 1929. Die Ehtstehung der Kontinente und Ozeane (4th edition). Friedrich Vieweg \& Sohn, Braunschweig. English translation by Biram, J. Published as The Origin of Continents and Oceans in the USA by Dover Publications Inc. and in the UK by Methuen, London. 1966 and 1967. 
Wilckens, O. 1932. Fossilien und Gesteine von Süd Georgien. Scientific Results of the Norwegian Antarctic Expedition 1927-1928, 8. I Kommisjon Hos Jacob Dybwad, Oslo.

Wilckens, O. 1933. Der Südantillen-Bogen. Geologische Rundschau, 24, 320-335.

Wilckens, O. 1937. Geologische Ergebnisse der Deutschen Süd Georgien Expedition Dr Kohl-Larsen 1928-29. Geologische Rundschau, 28, 127-128.

Wilson, J.T. 1966. Are the structures of the Caribbean and Scotia Arc regions analogous to ice rafting? Earth and Planetary Science Letters, 1, 335-338.

Wood, R.M. 1985. The Dark Side of the Earth. Allen \& Unwin, London. 246 pp.

Wordie, J.M. 1921. Shackleton Antarctic Expedition 1914-1917: Geological observations in the Weddell Sea area. Transactions of the Royal Society of Edinburgh, $53,17-27$.

\section{Figure Captions}

\section{Figure 1}

The geography of the Scotia Arc showing the principal tectonic features of the region simplified from Dalziel et al. (2013, figures 2 and 10). Some uncertainty remains at the boundary between the Scotia Sea and the Weddell Sea, which is a particularly complex zone.

Figure 2.

Outline geology of the Falkland Islands (after Aldiss and Edwards 1998).

Figure 3.

Outline geology of South Georgia (after Curtis and Riley 2011).

Figure 4.

The representation by Gregory (1901) of a restricted 'Scotia Arc' linking South America and Graham Land but closing well to the west of South Georgia.

Figure 5.

Part of the seminal reconstruction of Palaeozoic Gondwana by Du Toit (1937). Note particularly the position of the Falkland Islands, and the representation of the Scotia Arc looping into the 'Samfrau Geosyncline'. 'Samfrau' derives from South America Africa - Australia.

Figure 6.

Two contemporary but contrasting views of the origin of the Atlantic Ocean. 
a and b: Gregory (1929) illustrates a huge South Atlantic continent - Flabellites Land then Gondwanaland - surviving until the earliest Mesozoic before foundering between Africa and South America leaving South Georgia and the Falkland Islands as vestigial relics.

c: Holmes (1929) shows the Mesozoic South Atlantic widening as South America drifts westward away from Africa. The Scotia Arc is initiated as the continental link between South America and Graham Land ruptures and its fragments lag behind the drifting continents. Orogenic mountain belts form at the leading edges of the drifting continents.

Gregory uses a conventional Mercator map projection. Holmes uses an adaptation of a Cordiform projection. Different map projections undoubtedly fuelled early arguments over the 'fit' of continental margins, a point stressed by King (1953).

Figure 7.

The reconstruction of Gondwana presented by Joyce (1951, figure 2) at the 1950 meeeting of the British Association for the Advancement of Science, reproduced here by permission of The British Science Association. Joyce's original caption reads: "Part of Pangaea in Lower Palaeozoic times showing the Scotia Arc and part of the Antilles. The continental outlines are schematic. The pole of projection is marked by X.”

Figure 8.

The reconstruction of Gondwana published by King (1953, figure 1) which extended the geological links between South America and South Africa on into Antarctica. Despite drawing favourable attention in an earlier publication to the work of Adie, King omits Adie's (1952) rotation and repositioning of the Falkland Islands to the east side of South Africa (inset). Instead, the Falkland Islands are completely ignored.

Figure 9.

Hawkes' (1962) reconstruction of a linear orogenic belt linking Tierra del Fuego and Graham Land, before Cenozoic disruption and eastward drift dispersed terrestrial fragments into the Scotia Arc.

Figure 10

Two origins for the Scotia Arc 'rediscovered' in terms of plate tectonics.

a. Westward drift of South America and Antarctica leaves behind the disrupted fragments of an original connection, after Hamilton (1966). This idea can be traced back through Barth and Holmsen (1939) to Holmes (1929) and Wegener (1929).

b. The eastward migration of a Pacific island arc system breaks through the gap between South America and the Antarctic Peninsula (Graham Land), after Moores (1970). This is not that far removed from the situation envisaged by Hawkes (1962) who described a thin, rectilinear continental connection between South America and the Antarctic Peninsula disrupted by "an eastward advance of the Pacific crust”.

All concerned in these interpretations seem to have arrived independently at their solutions to the problem of the Scotia Arc. 


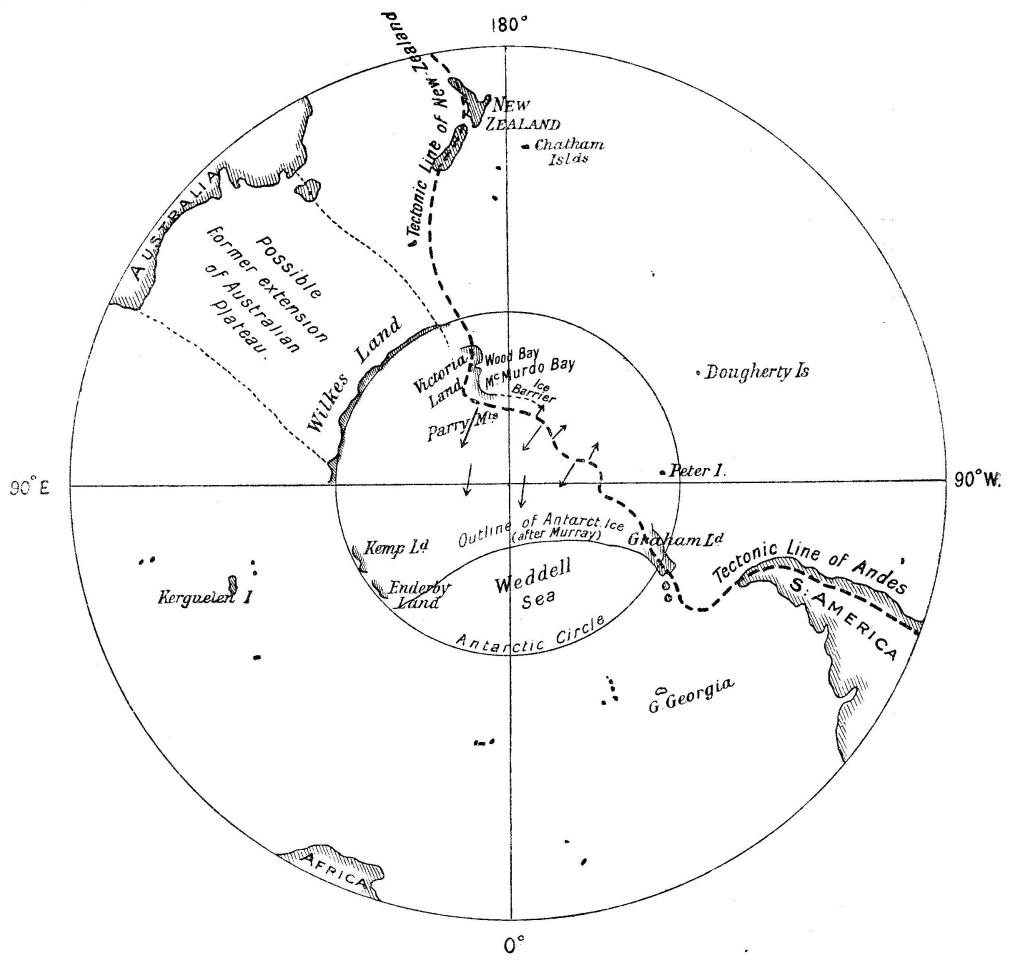




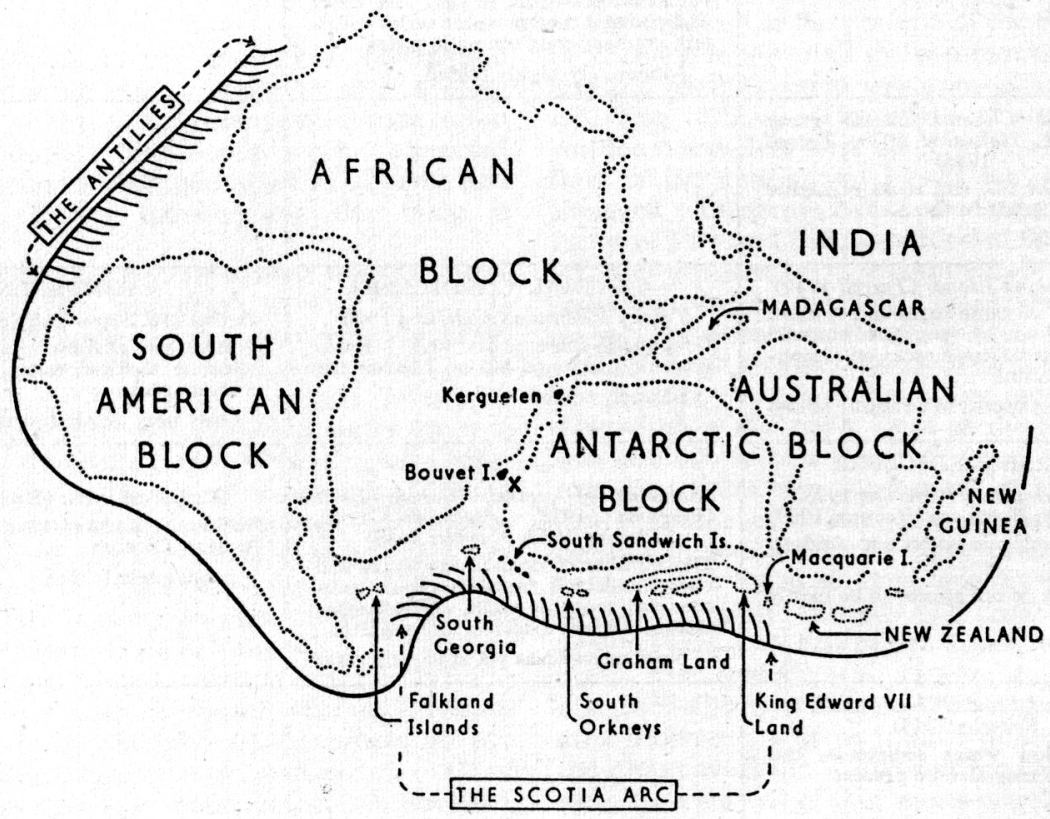




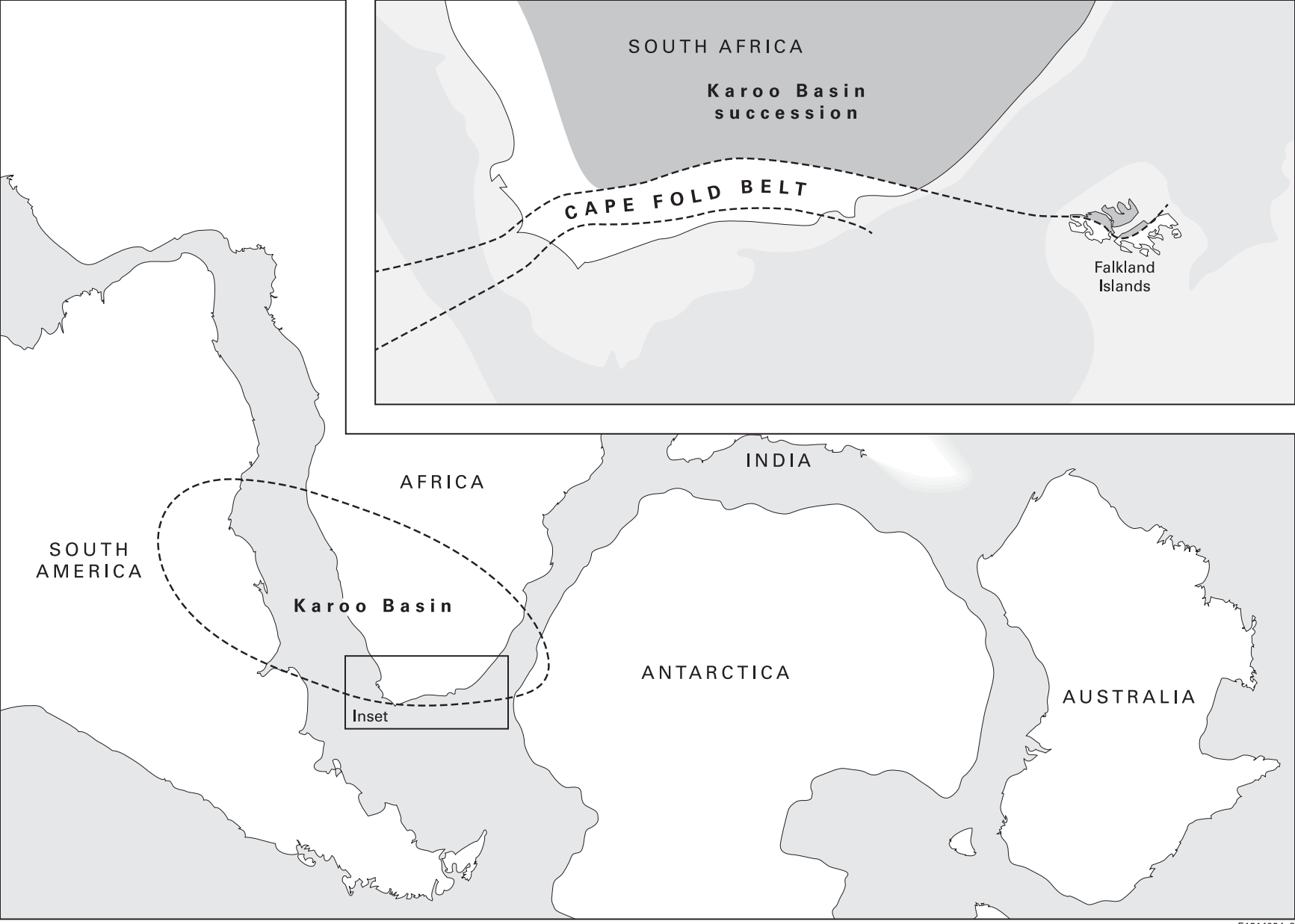


